\title{
МОНТТОРИНГ ПРОЦЕСУ ФОРМУВАННЯ ПРАВОВОЇ КУЛЬТУРИ МАЙБУТНІХ УЧИТЕЛІВ ІСТОРІї ТА ПРАВОЗНАВСТВА У ФАХОВІЙ ПІДГОТОВЦІ
}

\author{
Коваль Д. С., \\ Украйна, Умань, Уманський державний педагогічний університет імені Павла Тичини.
}

DOI: https://doi.org/10.31435/rsglobal_ws/30042020/7032

\section{ARTICLE INFO}

Received: 19 February 2020

Accepted: 17 April 2020

Published: 30 April 2020

\section{KEYWORDS}

monitoring,

formation of legal culture, future teachers of history and jurisprudence, professional training, educational process, special Secondary education (History), Jurisprudence, organizational and procedural components.

\begin{abstract}
The article monitors the process of forming the legal culture of future teachers of history and jurisprudence in professional training, which included analysis of the subjects taught in the educational program in the specialty Secondary Education (History). Jurisprudence, analysis of external and internal factors that influence the process of formation of legal culture. The causes of low formation of legal culture of future teachers of history and jurisprudence are established: low requirements for the process of its formation, legal units within the disciplines of professional training offered to study, presented in the standards of pedagogical specialties autonomously from the legal courses, lack of discretion plan, insufficient legal competence of teachers, which, due to the peculiarities of the content of the discipline, it is necessary to teach the norms of Ukrainian law, professional training of future teachers of history and jurisprudence does not correspond to the level of legal culture, which should be demonstrated by a specialist after graduation from higher education institution. The criteria for selecting the content and volume of legal information needed for future history and law teachers are highlighted.
\end{abstract}

Citation: Коваль Д. С. (2020) Monitorynh Protsesu Formuvannia Pravovoi Kultury Maibutnikh Uchyteliv Istorii ta Pravoznavstva u Fakhovii Pidhotovtsi. World Science. 4(56), Vol.3. doi: 10.31435/rsglobal_ws/30042020/7032

Copyright: (C) 2020 Коваль Д. С. This is an open-access article distributed under the terms of the Creative Commons Attribution License (CC BY). The use, distribution or reproduction in other forums is permitted, provided the original author(s) or licensor are credited and that the original publication in this journal is cited, in accordance with accepted academic practice. No use, distribution or reproduction is permitted which does not comply with these terms.

Вступ. Моніторинг основних складових освітнього процесу входить в систему управління якістю підготовки майбутніх учителів історії і правознавства дозволяє ним управляти, визначати напрями його вдосконалення, підвищуючи ефективність підготовки в цілому.

Педагогічний моніторинг являє собою процес збору, зберігання, обробки і поширення інформації про діяльність освітньої системи, що забезпечує безперервне науково-обгрунтоване, діагностично-прогностичне стеження за станом і розвитком освітнього процесу 3 метою оптимального вибору освітніх цілей, завдань і засобів їх вирішення. На це звертають увагу ряд авторів В. Боричевський [2], В. Владимирова [3], В. Воднік [4], І. Галущак [5], О. Ганзенко [6], Т. Горохівська [7], Л. Грищенко [8], Р. Клунко [9], Д. Пріма [11], О. Рем [14], А. Теслюк [15], П. Янченко [17]. Науковці доводять, що моніторинг процесу формування правової культури як планомірне відстеження його стану здійснюється з урахуванням вимог безперервності збору даних процесів, оптимальності, об'єктивності, валідності, надійності, систематичності, діагностичності, інформативності, науковості застосовуваних критеріїв і висновків, наявності зворотного зв'язку для внесення коректив у відстежуваний процес.

Метою моніторингу виступає діагностика сформованості правової культури майбутніх учителів історії і правознавства та внесення коректив в процес їх фахової підготовки, що 
включає діагностику, прогнозування та корекцію професійно-правового розвитку особистості і процесу фахової підготовки.

Моніторинг детермінується двома складовими: організаційною i процесуальною. Організаційний компонент моніторингу включає збір, зберігання, аналіз і інтерпретацію педагогічної інформації про досліджуваний процес; процесуальний компонент визначає цілі, зміст, методи і етапну організацію педагогічного моніторингу для виявлення конкретних результатів.

Моніторинг дозволяє судити про стан об'єкта в будь-який момент часу, виявляти характер змін за певний часовий період.

Суб'єктом моніторингу процесу формування правової культури майбутніх учителів історії та правознавства у фаховій підготовці виступають студенти спеціальності 014.03 Середня освіта (Історія). Правознавство та викладачі, які його забезпечують, а основними напрямами моніторингу $\epsilon$ якість умов формування правової культури, якість реалізації освітнього стандарту з метою формування правової культури, якість результатів освіти.

3 урахуванням сказаного в якості об’єктів моніторингу формування правової культури майбутніх учителів історії і правознавства виступають: відстеження труднощів у формуванні правової культури особистості; створення реального механізму формування правової культури; отримання інформації про сформованість правової культури; індивідуалізація діяльності 3 формування правової культури; виявлення і фіксація непередбачуваних, несподіваних відхилень у освітньому процесі.

П. Шахбанова пропонує до моніторингу включати різні форми його здійснення: стартову діагностику для корекції освітнього процесу, експрес діагностику з метою подальшого внесення коректив в освітню діяльність для побудови програм спостережень, проектування навчальних задач і ситуацій, фінішну діагностика, що визначає підготовленість студентів до професійної діяльності і ступеня розвитку специфічних професійних якостей [16, с.82].

Моніторинг процесу формування правової культури майбутнього вчителя історії і правознавства включає такі етапи:

- початково-діагностичний, спрямований на: визначення мети і завдань моніторингу; структурування показників правової культури майбутнього вчителя; підбір адекватних вимогам методик діагностики; проведення діагностики рівня правової культури майбутнього вчителя; кількісна та якісна обробка отриманих результатів і на їх основі вироблення педагогічного діагнозу;

- адаптаційний етап, який передбачає формування стійкої установки на отримання професійних знань і умінь; роботу кураторів і викладачів зі створення педагогічних умов для успішної адаптації студентів до освітнього процесу; встановлення і корекцію вихідних негативних тенденцій професійного становлення, що виникли в адаптаційний період у студентів; визначення вихідного індивідуального і групового рейтингу студентів;

- стабілізуючий етап передбачає стабілізацію проявів професійної та правової мотивації у навчальній діяльності і при проходженні педагогічної практики; попередню диференціацію професійних інтересів студентів; усунення можливих причин, що гальмують моніторинг формування правової культури майбутнього вчителя; визначення індивідуального і групового рейтингу студентів;

- перспективно-розвивальний етап передбачає прогнозування подальших тенденцій розвитку обстежуваного об'єкта; застосування методів і засобів, що дозволяють інтенсифікувати педагогічний процес; формування стійкої системи професійних знань і умінь; визначення індивідуального і групового рейтингу студентів;

- експертний етап передбачає визначення стійкості за професійним спрямуванням інтересів студентів; динаміки індивідуального і групового рейтингу впродовж усього періоду навчання.

Результати всіх видів рейтингу і аналіз навчальної документації, а також зміст роботи дозволили створити загальну картину освітнього процесу і рівень фахової підготовки та правової культури конкретного студента.

Отже, моніторинг $\epsilon$ необхідною умовою реалізації процесу формування правової культури майбутнього вчителя історії і правознавства і являє собою лонгітюдне дослідження стану педагогічного об'єкта, здійснюване протягом певного періоду часу. Основним механізмом визначення стану об’ єкта на етапах педагогічного моніторингу виступає діагностика. 
На основі вищезазначеного визначено завдання моніторингу: виявлення і фіксація ступеня сформованості правових знань, професійно-правових умінь, особистісно-правових аспектів у вчителів і студентів - першокурсників; визначення засобів педагогічної діагностики.

Результати дослідження. Вимоги суспільства до рівня фахової підготовки майбутнього вчителя історії і правознавства відображає Державний освітній стандарт та Освітня програма, що містить кваліфікаційну характеристику майбутнього вчителя історії і правознавства, зокрема до правових знань і вмінь.

Однак практика показує, що мінімальний рівень вимог не сприяє формуванню потреби педагогів у вдосконаленні правової культури. Аналіз змісту освітньої програми дозволяє стверджувати, що цей мінімум знижує мотивацію фахівця до побудови власної професійної діяльності відповідно до чинного законодавства.

Причина 1. Зазначені в стандартах з педагогічних спеціальностей вимоги до майбутніх учителів історії і правознавства орієнтовані, перш за все, на формування здатності студентів усвідомлювати необхідність дотримання прав і свобод учнів, передбачених законом.

Обмеженість такої вимоги обумовлює домінуюче сприйняття студентом тези про те, що учень має права і свободи. Така позиція знижує гостроту розуміння того, що суб'єктивні права завжди взаємопов'язані з юридичними обов'язками, якими наділяється будь-який учасник правовідносин, а невиконання або неналежне виконання цих обов'язків тягне за собою застосування юридичної відповідальності.

Переважне вивчення в правових дисциплінах змісту прав дитини не дозволяє студенту чітко виділити перелік видів її обов'язків обумовлених законом. Вивчення способів захисту прав дитини призводить до того, що забувається складність суб'єктного складу такого учасника правовідносин як учень. Дитина як учасник освітніх правовідносин в ряді випадків реалізує свої права і обов'язки через законних представників, а це породжує необхідність знання педагогом прав, свобод, обов'язків і видів відповідальності не тільки дитини (учня), а й іiі батьків (законних представників). Аналіз стандартів та освітньої програми показує, що вивчення прав, обов'язків, відповідальності і свобод такого учасника освітнього процесу, як батьки, в стандарті не передбачено.

Знання правового статусу учнів i ïx законних прав неможливо продемонструвати на основі тієї мінімальної кількості нормативних правових актів, уявлення про які повинен демонструвати випускник-педагог після закінчення закладу освіти. Освітня програма передбачає обов'язкове знання випускниками мінімум одного закону України (Закон України «Про освіту») і одного міжнародного правового акта (Конвенція про права дитини).

Цілком зрозуміло, що жорстке обмеження кількості нормативних правових актів, які повинен знати майбутній учитель історії і правознавства не сприяє розширенню його правового кругозору. Мінімум правових знань практично не відображає системного розуміння права i не формує у студентів цілісного сприйняття освітнього законодавства як частини законодавства країни.

Отже, перша причина низької сформованості правової культури майбутніх учителів історії і правознавства - це занижені вимоги до процесу іiі формування.

Причина 2. Аналіз правових компетентностей за спеціальністю Середня освіта (Історія). Правознавство показує, що студенти освоюють їх не тільки в рамках правових дисциплін, а й в рамках дисциплін, які не належать до правових.

Кожна навчальна дисципліна здійснює свій внесок у формування системи правових знань, але ми розглядаємо лише основні з цих дисциплін.

Вивчення деякої загальної частини правової інформації частково розподілено між психолого-педагогічними, історичними та правовими дисциплінами. Дисципліни, що входять в ці цикли, дають правові знання та вміння, формують професійно-правові якості особистості, складові готовності майбутнього педагога до правового виховання учнів і правової самоосвіти. Правові дидактичні одиниці зосереджені в навчальних курсах за вибором. Навчальний план містить правові дидактичні одиниці, крім правових курсів в таких навчальних дисциплінах як: філософія, фізичне виховання, історія держави і права України, педагогіка, вікова фізіологія, шкільна гігієна, охорона праці та безпека життєдіяльності, теорія і методика навчання історії, історична географія України (таблиця 1). 
Таблиця 1. Правові дидактичні одиниці в навчальних дисциплінах

\begin{tabular}{|c|c|}
\hline Дисципліна & Правові дидактичні одиниці \\
\hline Філософія & Мораль, справедливість, право (3 дидакт. одиниці) \\
\hline $\begin{array}{l}\text { Фізичне } \\
\text { виховання }\end{array}$ & Законодавство України про фізичну культуру і спорт (1 дидакт. одиниця) \\
\hline $\begin{array}{l}\text { Iсторія держави i } \\
\text { права України }\end{array}$ & $\begin{array}{l}\text { Держава і право. Їх роль в житті суспільства. Норма права і нормативно- } \\
\text { правові акти. Основні правові системи сучасності. Міжнародне право як } \\
\text { особлива система права. Джерела українського права. Закон і підзаконні акти. } \\
\text { Система українського права. Галузі права. Правопорушення і юридична } \\
\text { відповідальність. Значення законності і правопорядку в сучасному } \\
\text { суспільстві. Правова держава. Конституція України - основний закон } \\
\text { держави. Система органів державної влади в Україні. Понятяя цивільних } \\
\text { правовідносин. Фізичні та юридичні особи. Право власності. Зобов'язання в } \\
\text { цивільному праві і відповідальність за їх порушення. Право соціального } \\
\text { забезпечення. Шлюбно-сімейні відносини. Взаємні права і обов'язки } \\
\text { подружжя, батьків і дітей. Відповідальність з питань сімейного права. } \\
\text { Трудовий договір (контракт). Трудова дисципліна та відповідальність за ії } \\
\text { порушення. Адміністративні правопорушення і і адміністративна } \\
\text { відповідальність. Поняття злочину. Кримінальна відповідальність за } \\
\text { вчинення злочинів. Екологічне право. Особливості правового регулювання } \\
\text { майбутньої професійної діяльності. Правові основи захисту державної } \\
\text { таємниці. Законодавчі та нормативно-правові акти у сфері захисту інформації } \\
\text { та державної таємниці (31 дидакт. одиниця) }\end{array}$ \\
\hline Педаго & $\begin{array}{l}\text { Управління освітніми системами. Основні види освітніх закладів. } \\
\text { Підвищення кваліфікації та атестація працівників школи. Нормативно- } \\
\text { правове забезпечення освіти. Законодавство в галузі освіти. Права дитини і } \\
\text { форми ії правового захисту в законодавстві України. Особливості правового } \\
\text { забезпечення педагогічної діяльності. Нормативно-правові та організаційні } \\
\text { основи діяльності освітніх закладів. Правове регулювання відносин в } \\
\text { системі освіти і правовий статус учасників освітнього процесу. Основні } \\
\text { правові акти міжнародного освітнього законодавства. Співвідношення } \\
\text { українського і зарубіжних законодавств в галузі освіти. Нормативно-правове } \\
\text { забезпечення модернізації педагогічної освіти в Україні (12 дидакт. одиниць) }\end{array}$ \\
\hline $\begin{array}{l}\text { Вікова фізіологія, } \\
\text { шкільна гігієна }\end{array}$ & $\begin{array}{l}\text { Гігієна освітнього процесу в школі. Гігієнічні основи режиму дня учнів. } \\
\text { Гігієна трудового навчання і продуктивної праці учнів. Гігієнічні вимоги до } \\
\text { планування шкільної будівлі, земельної ділянки (4 дидакт. одиниці) }\end{array}$ \\
\hline $\begin{array}{l}\text { Охорона праці та } \\
\text { безпека } \\
\text { життєдіяльності }\end{array}$ & $\begin{array}{l}\text { Організація антитерористичних заходів в освітньому закладі. Захисні } \\
\text { споруди цивільної оборони. Організація захисту населення в мирний і } \\
\text { воєнний час. Організація цивільної оборони в освітніх закладах (4 дидакт. } \\
\text { одиниці) }\end{array}$ \\
\hline $\begin{array}{l}\text { Теорія і методика } \\
\text { навчання історії }\end{array}$ & $\begin{array}{l}\text { Теоретичні основи держави і права. Етапи розвитку громадянського } \\
\text { суспільства. Правові пам’ятки. Розвиток права в його різноманітті. Основні } \\
\text { ідеї і принципи, зафіксованих в середині ХХ століття в Загальній декларації } \\
\text { прав людини. Діяльність державних органів та закладів в політичному, } \\
\text { господарському, культурному житті суспільства, в міжнародних відносинах } \\
(6 \text { дидакт. одиниць) }\end{array}$ \\
\hline $\begin{array}{l}\text { Історична } \\
\text { географія } \\
\text { України }\end{array}$ & $\begin{array}{l}\text { Природні, соціальні і економічні аспекти прав людини. Закон природи. } \\
\text { Збереження навколишнього середовища, як в місцевому, так і глобальному } \\
\text { масштабі. Взаємозв’язок прав людини, природи і суспільства в цілому (4 } \\
\text { дидакт. одиниці) }\end{array}$ \\
\hline
\end{tabular}


Понад 30 понять, термінів, правових категорій пропонується до вивчення в навчальних дисциплінах, що не відносяться до правових. Вони жодним чином не пов'язані між собою і не спираються на знання студентами основ українського права.

Отже, причина друга полягає в тому, що пропоновані до вивчення правові дидактичні одиниці в рамках дисциплін фахової підготовки, представлені в стандартах з педагогічних спеціальностей автономно від правових курсів та пояснюється відсутністю окремої дисципліни «Правознавство» у навчальному плані.

Причина 3. Значна частина правових знань формуються в межах правових дисциплін, які є варіативними.

Будь-яка навчальна дисципліна являє собою систему знань, умінь, навичок, відібраних 3 певної галузі науки, виробничої діяльності для вивчення в освітньому закладі. Тому завданнями дисципліни повинно було б бути не розкриття ролі і формулювання завдань освіти в сучасному суспільстві, а формування знань студентів про особливості нормативного правового забезпечення галузі, розвиток у них умінь в порівнянні українського і міжнародного законодавства в галузі освіти, вдосконалення навичок систематизації, узагальнення, розробки нормативних документів (роботи з документами).

Побіжне знайомство з системою українського права, галузями права призводить до пасивного сприйняття законодавства країни, не сприяє формуванню потреби самоосвіти в галузі права.

Недолік фахової підготовки з питань правового статусу педагогічного працівника, учня, освітнього закладу, освітнього законодавства заповнюється за допомогою дисциплін цієї підготовки, зокрема педагогічних та методичних. Тим самим передбачається, що викладати їх повинні не юристи-правознавці, а викладачі педагогічних дисциплін, які не мають спеціальної правової підготовки.

Основний зміст фахової підготовки реалізується в дисциплінах «Теорія держави і права», «Конституційне право України», «Сімейне право України», «Адміністративне право України», «Кримінальне право України», «Методика навчання правознавства», «Цивільне і господарське право України», «Аграрне та екологічне право України», «Трудове право України», «Муніципальне право України», «Земельне право України», «Житлове право України», «Фінансове право України», «Право соціального забезпечення» та ін. У цих дисциплінах передбачено характеристику правовідносин, регульованих нормами різної галузевої приналежності, зокрема й тих, що виникають «всередині» освітнього процесу, пов'язані з його організацією і здійсненням; інші види правовідносин у сфері освіти, пов'язані з необхідністю матеріального, кадрового, фінансового та іншого забезпечення діяльності у досягненні освітніх цілей і завдань. Ці відносини регулюються нормами відповідних галузей права: трудового (прийом на роботу педагогічних працівників та укладання відповідних трудових договорів (контрактів), встановлення режиму робочого дня i відпочинку тощо); цивільного (встановлення організаційно-правових форм освітніх закладів, укладання господарських договорів, надання платних освітніх послуг, захист особистих немайнових прав тощо); адміністративного (управління і контроль, атестація педагогічних працівників, ліцензування та акредитація діяльності освітніх закладів тощо); фінансового (фінансове забезпечення діяльності освітніх закладів та ін.); соціального забезпечення (встановлення пільг, допомоги суб'єктам освітніх відносин тощо).

Ці дані показують, що рівень складності правових дидактичних одиниць пропонованих до вивчення в рамках зазначених дисциплін досить високий. Розкриття навіть однієї дидактичної правової одиниці вимагає знання всього українського законодавства, володіння міждисциплінарною підготовкою, наявності практичного досвіду роботи в галузі.

Вивчення правових дисциплін йде паралельно з вивченням педагогічних і історичних дисциплін, відбувається поетапне i паралельне оволодіння правовими, педагогічними i історичними знаннями, формуються особистісно-правові якості педагога і вміння правового характеру. Відбувається усвідомлення ролі та місця педагогічної діяльності в освітньому процесі. На основі органічного вбудовування правових знань в систему педагогічних i історичних знань відбувається їх взаємне насичення і збагачення, створюється фундамент для утворення системи, що дозволяє інтегрувати загальнопедагогічні, правові, історичні знання та вміння з подальшою реалізацією їх на практиці. 
Однак згідно аналізованих освітніх стандартів зі спеціальності Середня освіта (Історія). Правознавство складні, з погляду правового забезпечення, дидактичні одиниці такі як: співвідношення зарубіжного і українського законодавства в галузі освіти, політика держави щодо забезпечення прав громадян на освіту, захист дитинства, підтримки інвалідів, правове регулювання сімейних відносин, комплексний підхід до визначення охоронно-гігієнічних заходів в освітніх закладах, передбачено до викладання викладачами, які не мають спеціальної правової підготовки. Імовірність того, що при поясненні сенсу юридичних конструкцій акценти будуть зміщені в бік корпоративної (педагогічної) етики, досить висока. Це відповідно не дозволяє сформувати у студентів кваліфіковану стійку систему правових знань.

Отже, третя причина низької сформованості правової культури майбутніх учителів історії і правознавства полягає в недостатній правовій компетентності викладачів, яким в силу особливостей змісту навчальної дисципліни необхідно викладати норми українського законодавства.

Причина 4. Особливого значення набуває в даний час спеціальна правова підготовка вчителів історії і правознавства. Це продиктовано не тільки змінами змісту стандарту загальної середньої освіти, в якому предмет «Правознавство» включений до базового компоненту освіти, а й збільшеною потребою в фахівцях, що поєднують функції педагогічного працівника і юриста.

Аналіз стандарту за фахом спеціальністю Середня освіта (Історія). Правознавство показує, що базова фахова підготовка адекватна класичній підготовці фахівців за кваліфікацією «Юрист». Психолого-педагогічний блок циклу професійної підготовки включає традиційні для педагогічної освіти дисципліни: «Педагогіка», «Психологія», а блок фундаментальної підготовки циклу загальної підготовки доповнений дисциплінами, що визначають соціальну значимість зазначеної кваліфікації («Вікова фізіологія, шкільна гігієна», «Фізичне виховання», «Історія української культури», «Історія держави і права України»).

Традиційне розуміння галузі права, труднощі у визначенні предмета правового регулювання, формуванні понятійного апарату галузі освіти призводять до того, що в професійному юридичному середовищі питання про існування освітнього права, як галузі права поки дискусійне. Проте, динамічне оновлення, розвиток українського освітнього законодавства примушує багатьох дослідників визнавати, що в українській правовій системі формується самостійне «правове поле». Аналогічно вже визнаними галузями права є Житлове право України, Аграрне та екологічне право України. Цим пояснюється відсутність у навчальному плані дисципліни «Правознавство». Проте іiі матеріал знаходимо у дисципліні «Методика навчання правознавству», що дозволяє продовжити розвиток умінь і навичок з правової освіти. Ця дисципліна пропонується до вивчення студентам старших курсів, що дозволяє на прикладі конкретної галузі відпрацювати правові вміння і навички. Основний акцент зроблений на відпрацюванні загальних категорій: предмет i об'єкт, метод правового регулювання, правовідносини, правосуб'єктність, правовий статус суб'єкта правовідносин, юридична відповідальність, юридична особа, законодавство, освітнє право як фундаментальна складова освіти, законодавчої та нормативної бази функціонування системи освіти України, організаційних основ і структури управління освітою, механізмів і процедур управління якістю освіти, а також формування у майбутніх педагогів знань і умінь для роботи в освітньому правовому просторі, морально-правове виховання учнів; розвиток правового статусу учня і педагога; надання допомоги в правовому регулюванні взаємодій освітнього закладу, сім'ї учня, органів управління освітою, громадськості.

У той же час педагогічна практика показує, що найбільші труднощі викликають спеціальні питання: правова безпека освітнього закладу, дисциплінарне розслідування, ліцензування, атестація, гарантії в сфері освіти, процесуальні взаємини, діловодство юридичної особи, вирішення конфліктних питань, нормативне планування ризиків в освіті, специфіка соціальної підтримки суб'єктів. Саме в цьому курсі необхідно передбачити правовий аналіз правовиховної діяльності педагога в школі. Зокрема мова йде про те, що іноді, не знаючи законодавства, вчитель, виконуючи обов'язки класного керівника, розмовляючи з батьками учнів з неблагополучних сімей, не може грамотно викласти їх обов'язки та відповідальність за належне виховання своїх дітей.

Порівняльний аналіз стандартів 3 педагогічних (неюридичних) і юридичних спеціальностей дозволяє зробити висновок про те, що вчитель історії і правознавства як юрист у сфері освіти не зможе надати правову допомогу своїм колегам, оскільки не володіє знаннями щодо таких 
дидактичних одиниць як: державні стандарти щодо документування, гігієнічні основи харчування, санітарні норми на умови праці, загальні вимоги безпеки праці та виробничої санітарії та ін.

Отже, причина четверта полягає в тому, що правова підготовка майбутніх учителів історії і правознавства не відповідає тому рівню правової культури, який повинен демонструвати фахівець після закінчення закладу вищої освіти.

Аналіз дисциплін, що викладаються в рамках освітньої програми за спеціальністю Середня освіта (Історія). Правознавство показав, що в навчальному плані є достатня кількість дисциплін, які орієнтовані на формування правової культури. Однак при аналізі зовнішніх і внутрішніх факторів, що впливають на процес формування правової культури встановлено, що традиційна підготовка майбутніх учителів історії і правознавства не володіє необхідною продуктивністю - молоді вчителі мають ряд проблем з використанням правового матеріалу в професійній діяльності, не володіють навичками саморозвитку і в цілому мають низьку правову культуру.

Проведений аналіз показав, що фахова підготовка майбутніх учителів історії i правознавства відірвана від практики педагогічної діяльності, носить в основному академічний, а не прикладний характер. Цей висновок визначив необхідність посилення фахової підготовки майбутніх учителів історії і правознавства у напрямі формування у них правової культури за рахунок інтеграції теорії і практики педагогічної діяльності.

На сьогоднішній день потребує перегляду як обов’язковий мінімум змісту основної освітньої програми фахової підготовки майбутніх педагогів, так і вимоги до правової освіченості (підготовленості) майбутнього педагога, в які необхідно додати також такі вимоги як: повинен мати сформовану систему ціннісно-правової орієнтації, високий рівень правосвідомості і правової культури; вміння здійснювати правове виховання учнів і усвідомлювати необхідність самостійного підвищення рівня своєї правової освіти.

Слід зазначити, що для студентів педагогічних ЗВО можливим є використання програм і навчальних посібників, складених для студентів юридичних закладів вищої освіти (А. Берлач [1], П. Рабінович [13], С. Тимченка [11]). Однак правова інформація і іï обсяг для майбутніх учителів історії і правознавства повинні відображати специфіку i особливості саме педагогічного закладу освіти.

Виділені критерії з відбору правового змісту, принципи його розробки і особистий досвід автора у викладанні історичних і правових дисциплін дозволили виділити той обсяг правової інформації, який необхідний для майбутніх вчителів історії і правознавства.

Грунтуючись на роботах М. Мотехіної [10, с.73], яка пропонує здійснювати інтеграцію змісту правової і професійно-педагогічної освіти, виділяємо такі критерії відбору змісту фахової підготовки студентів у напрямі формування у них правової культури.

Критерій особистого статусу, громадянина України, професійної майбутньої діяльності, соціально-правового статусу студента, його правова діяльність і правове виховання. Підготовка студента до професійної діяльності повинна враховувати, ті життєві процеси, що реально відбуваються в суспільстві, особливо в законодавстві, зачіпають сферу вищої педагогічної освіти, задовольняють правові інтереси особистості.

Критерій включення в досліджуваний матеріал максимуму правових норм профілактичного характеру. Від впливу негативних явищ не застраховане жодне суспільство, ні особистість. Людина живе в суспільстві i, отже, не може не відчувати впливу негативних факторів життя. У зв'язку з цим в матеріалі, що є важливим для правової підготовки студентів, необхідна наявність норм права, які формують «імунітет» до правопорушень в будь-якому їх прояві.

Критерій стимулювання особистості до активної правоохоронної позиції. Він сприяє підвищенню захисних сил особистості, опірності іï правопорушенням. Формується зріла громадянська позиція.

Тому необхідно стимулювати соціально-правову діяльність майбутніх педагогів. Ця діяльність закріплює отримані теоретичні знання, прищеплює професійно-правові вміння [10, с.74].

Величезну роль у формуванні у студентів системи правових знань відіграють міжпредметні зв'язки правових дисципліни 3 психолого-педагогічними і історичними дисциплінами. Важливу роль в процесі правового навчання студентів покликана зіграти система міжпредметних зв'язків курсів теорії держави і права, адміністративного, цивільного, трудового, екологічного, кримінального та сімейного права, які забезпечують спадкоємний зв’язок з першого по четвертий курс. 
Аналіз змісту дисциплін фахової підготовки майбутніх учителів історії і правознавства вказує на необхідність введення системи спецсемінарів, які супроводжували б навчання студента протягом всього періоду підготовки у ЗВО і виконували б базову функцію при розкритті спеціальних правових питань в дисциплінах предметної підготовки.

Для формування цілісного сприйняття системи освіти України, для розвитку правового кругозору, розуміння складності правової взаємодії окремих інститутів системи освіти, пропонується ввести спецсемінари «Правова культура майбутнього вчителя історії i правознавства», «Основи правовиховної роботи в школі», Створення, оновлення та захист інформації відповідно до змін в законодавстві», рефлексивний спецсемінар.

Поглиблює і закріплює правові знання студентів правова та педагогічна практики. Їх основна мета - підготовка майбутніх вчителів історії та правознавства як організаторів правоохоронної роботи з учнями та представників 3 прав учнів при вирішенні конфліктних ситуацій.

За період правової практики майбутні вчителі історії та правознавства повинні навчитися: планувати правове виховання школярів; складати документацію з правових питань; підготувати доповіді, повідомлення, реферати, бесіди та лекції для правової пропаганди перед учнями та їх батьками, в трудових колективах; організації та проведення правових вечорів, рольових ігор, бесід за круглим столом, олімпіад; керувати шкільними правоохоронними загонами; використовувати правовий потенціал свого предмета для посилення ефективності правового виховання; провести і проаналізувати правовий захід; вміти взаємодіяти 3 правоохоронними органами та громадськими організаціями в правовому вихованні школярів; брати активну участь у правоохоронній діяльності.

Педагогічна практика майбутніх учителів історії і правознавства полягає у формуванні специфічних професійно-педагогічних умінь; вивченні особливостей пізнавальної діяльності учнів; обгрунтованому відборі і використанні різноманітних форм, методів і засобів навчання, методів виховання з урахуванням вікових та індивідуальних особливостей учнів і їх колективу; практичному застосуванні і поглибленні знань, набутих в процесі теоретичного навчання; вихованні якостей соціально активної особистості.

Обидві практики спрямовані на формування навичок роботи з різними категоріями дітей та координацію зусиль школи, сім’і, державних органів (органів управління освітою, органів місцевого самоврядування, комісій у справах неповнолітніх, відділень внутрішніх справ).

Висновки. Аналіз дисциплін, що викладаються в рамках освітньої програми за спеціальністю Середня освіта (Історія). Правознавство показав, що в навчальному плані $\epsilon$ достатня кількість дисциплін, які орієнтовані на формування правової культури. Однак при аналізі зовнішніх і внутрішніх факторів, що впливають на процес формування правової культури встановлено, що традиційна підготовка майбутніх учителів історії і правознавства не володіє необхідною продуктивністю - молоді вчителі мають ряд проблем з використанням правового матеріалу в професійній діяльності, не володіють навичками саморозвитку і в цілому мають низьку правову культуру.

Встановлені причини низької сформованості правової культури майбутніх учителів історії і правознавства: занижені вимоги до процесу iї формування, пропоновані до вивчення правові дидактичні одиниці в рамках дисциплін фахової підготовки, представлені в стандартах 3 педагогічних спеціальностей автономно від правових курсів, відсутність окремої дисципліни «Правознавство» у навчальному плані, недостатня правова компетентність викладачів, яким в силу особливостей змісту навчальної дисципліни необхідно викладати норми українського законодавства, фахова підготовка майбутніх учителів історії і правознавства не відповідає тому рівню правової культури, який повинен демонструвати фахівець після закінчення закладу вищої освіти.

Виділені критерії відбору змісту і обсягу правової інформації, який необхідний для майбутніх вчителів історії і правознавства.

\section{ЛIТЕРАТУРА}

1. Берлач А. І., Карпенко Д. О., Ковальський В. С. та ін. Правознавство: підручник/ за ред. В. В. Копейчикова, А. М. Колодія. Київ: Юрінком Інтер, 2007. 752 с.

2. Боричевський В. Проблеми формування правової культури педагога. Вісник Національного авіаційного університету. Серія: Педагогіка, психологія. 2009. № 1. С. 51-54.

3. Владимирова В. І. Теорія i практика формування правової культури майбутнього вчителя (педагогічно-правовий аспект 1917-2002 рр.). Кіровоград: [Б. в.], 2010. 252 с. 
4. Воднік В. Д. Проблеми правового виховання і формування правової культури. Правова культура $i$ громадянське суспільство в Украӥні: стан і перспективи розвитку: матеріали Міжнар. наук. конф. (Харків, 12 жовт. 2007 р.). Харків: Право, 2007. С. 15-16.

5. Галущак I. С. Формування правової культури майбутніх економістів. Основні напрями розвитку педагогічної науки: матеріали II Міжнар. наук.-практ. конф. (Чернігів, 20-21 жовт. 2017 р.). Херсон: Видавничий дім «Гельветика», 2017. С. 88-89.

6. Ганзенко О. О. Формування правової культури особи в умовах розбудови правової держави Україна: автореф. дис. ... канд. юрид. наук: 12.00.01. Київ, 2003. 20 с.

7. Горохівська Т. М. Формування світоглядної культури майбутніх вчителів історії у процесі фахової підготовки: дис. ... канд. пед. наук: 13.00.04. Суми, 2009. 264 с.

8. Грищенко Л. В. Стан формування правової культури майбутніх учителів у навчально-виховному середовищі педагогічного коледжу. Вісник Черкаського університету. Серія : Педагогічні науки. 2017. Вип. 15. С. 29-36.

9. Клунко Р. Ю. Формування правової культури майбутнього вчителя як елемент підготовки до професійної діяльності. Наукові записки НДУ ім. М. Гоголя. Серія : Психолого-педагогічні науки. 2015. № 3. C. 148-151.

10. Мотехина М. В. Правовая подготовка будущего учителя в учебном процессе педагогического вуза: дис. ... канд. пед. наук: 13.00.01. Тула, 2000. 223 с.

11. Правознавство: навч. посіб. / за ред. С. М. Тимченка, Т. О. Коломієць. 2-ге вид., стереотип. Суми: ВТД «Університетська книга», 2008. 554 с.

12. Пріма Д. А. Формування правової культури майбутнього керівника загальноосвітнього навчального закладу у процесі магістерської підготовки: автореф. дис. ... канд. пед. наук: 13.00.02. Черкаси, 2013. 20 с.

13. Рабінович П. М. Основи загальної теорії права та держави: навч. посіб. 9-те вид., перероб. Львів: Край, 2007. 192 с.

14. Рем О. Педагогічні умови формування правової культури педагога професійного навчання. Проблеми підготовки сучасного вчителя. 2012. № 6, Ч. 1. С. 68-73.

15. Теслюк А. С. Формування правової культури студентів - майбутніх учителів. Педагогіка, психологія та медико-біологічні проблеми фізичного виховання і спорту. 2006. № 1. С. 105-107.

16. Шахбанова П. Г. Организационно-педагогические условия формирования коммуникативной культуры будущего учителя права: дис. ... канд. пед. наук: 13.00.08. Махачкала, 2012. 210 с.

17. Янченко П. В. Формування правової культури майбутніх юристів у процесі фахової підготовки : автореф. дис. ... канд. пед. наук: 13.00.04. Хмельницький, 2019. 20 с. 